\title{
EFFECTS OF A NONSTEROIDAL ANTIFERTILITY AGENT (U-11100A) ON PREGNANCY IN MICE
}

\author{
JOAN THOMSON TENBROECK AND RALPH L. BRINSTER \\ King Ranch Laboratory of Reproductive Physiology, School of Veterinary Medicine, \\ University of Pennsylvania, Philadelphia, Pennsylvania
}

(Received 1st March 1968)

\begin{abstract}
Summary. The effect of an antifertility agent, U-11100A, on the development in vitro of early mouse embryos and on pregnancy in mice was studied in order to examine the mode of action of the compound.

It was found that development in vitro was blocked at a concentration of $20 \mu \mathrm{g} / \mathrm{ml}$ of U-11100A and that pregnancy was terminated by the oral administration of $10 \mathrm{mg} / \mathrm{kg}$ on any of the first 4 days after mating.

When the compound was administered while the embryos were still in the oviducts, acceleration of tubal transport occurred. If it was given after the embryos had reached the uterus, implantation failed to occur, and the embryos were lost through the vagina.

Thus it appears that, in mice, the compound acts on the maternal reproductive tract rather than on the embryo itself.
\end{abstract}

\section{INTRODUCTION}

The use of certain nonsteroidal compounds as oral antifertility agents has been the subject of many investigations in the last few years. The compounds are numerous and include such agents as clomiphene (Merrill Co.), U-11555A (Upjohn Co.) and U-11100A (Upjohn Co.). All of these compounds have been tested in rats and have been effective in terminating pregnancy if administered on any of the first 4 days after mating. In this laboratory, clomiphene and U-11555A have been used in studies of the effects of the compounds on the development in vitro of two-celled mouse embryos, as well as in studies of their effects on pregnancy in mice. It was found that these two compounds interfered with pregnancy both by retarding passage of embryos through the oviducts and by preventing implantation.

The present investigation involved a similar study of the effects of U-11100A on zygote development and on pregnancy in mice. The compound was added to culture medium to test the effect on development in vitro and was fed to mice by gavage to determine the effects on pregnancy.

\section{MATERIALS AND METHODS}

Two-celled embryos used in culture experiments were obtained from Swiss mice which had been superovulated with 5 i.u. of pregnant mare serum 
gonadotrophin (PMSG), followed $48 \mathrm{hr}$ later with 5 i.u. of human chorionic gonadotrophin (HCG), and mated with Swiss males. For studying the effects of the compound on pregnancy, ovulation of the mice was synchronized by the injection of 2 i.u. PMSG followed $48 \mathrm{hr}$ later by 2 i.u. HGG. The mice were mated with Swiss males immediately after the second injection, and the day on which the copulation plug was found was designated Day 1 of pregnancy. Using the above preparatory methods, four different experiments were carried out, using the antifertility compound.

\section{Determination of dose response in vitro}

Two-celled embryos were collected from pregnant mice by flushing the oviducts with culture medium on the 2nd day after mating (Brinster, 1963, 1965). The embryos were cultured in small drops of medium under $10 \mathrm{ml}$ of light-weight paraffin oil in $15 \times 60 \mathrm{~mm}$ plastic tissue culture dishes. The dishes were maintained at $37^{\circ} \mathrm{C}$, in an atmosphere of humidified $5 \% \mathrm{CO}_{2}$ in air, for 3 days. During this time most untreated embryos developed from the two-celled stage into blastocysts.

Preliminary experiments involved a large range of concentrations of $\mathrm{U}-11100 \mathrm{~A}$ in order to determine the effective inhibitory area. In the final experiments five concentrations were used, following a geometrical progression of two. In all experiments twelve embryos were placed in each drop, and two drops were allotted to each treatment. An experiment was scored at the end of the culture period by counting the number of morphologically normal blastocysts which had developed from the two-celled embryos. The fractional score from each drop was converted to an angle, and the transformed data were examined by an analysis of variance (Biggers \& Brinster, 1965).

\section{Determination of dose response in vivo}

Preliminary experiments were designed to determine the range of effective antifertility doses of U-11100A. In final experiments, four groups were given four different single doses on Day 2 of pregnancy. Four other groups were given four different quadruple doses on Days 1 to 4 .

For each experiment, ten mice were allotted randomly to each of the eight treatment groups. The antifertility compound was fed to the mice in $0.1 \mathrm{ml}$ of water by gavage (Thomson, 1968a). Control mice were fed with distilled water.

All of the mice were killed on Day 10 of pregnancy, and the experiment was scored by counting the number of implantation sites per mouse, including foetuses which were being resorbed or aborted.

\section{Effect on tubal transport rate}

For this experiment, eighty pregnant mice were randomized into eight groups of ten mice. Using the lowest effective dose determined in the previous experiment $(10 \mathrm{mg} / \mathrm{kg})$, four of the groups were given the antifertility compound by gavage on Day 2 of pregnancy; mice in the other four groups were given $0.1 \mathrm{ml}$ of water on the same day.

Ten treated and ten control mice were killed on each of the 3rd, 4th, 5th and 
8th days of pregnancy. On each occasion the oviducts and the uterine horns were removed from the twenty mice and the contents of each oviduct and each horn were flushed out separately with culture medium. The embryos obtained were scored according to location, number, stage and condition. For each of the 4 days, the total numbers of embryos recovered from control and from treated animals were compared using a $t$-test.

\section{Effect on implantation}

Forty pregnant mice were randomly allotted to four groups of ten mice. On Day 4 of pregnancy, twenty mice were given $10 \mathrm{mg} / \mathrm{kg}$ of U-11100A by gavage; twenty mice were given water. Ten treated and ten control mice were killed on both the 5th and 9th days of pregnancy. The oviducts and uterine horns of each mouse were flushed separately and the contents were scored as in the preceding section.

\section{RESULTS}

Dose response in vitro

The results of three similar experiments are presented in Table 1. The four lowest concentrations of U-11100A allowed normal development of a majority

TABLE 1

EFFECT OF U-11100A ON THE DEVELOPMENT OF TWO-GELL EMBRYOS INTO BLASTOCYSTS IN VITRO

\begin{tabular}{|c|c|c|c|c|c|c|c|c|}
\hline \multirow{2}{*}{$\begin{array}{c}\begin{array}{c}\text { Concentration } \\
\text { of } U-11100 A \\
(\mu g / m l)\end{array} \\
0 \\
1 \cdot 25 \\
2 \cdot 5 \\
5 \\
10 \\
20\end{array}$} & \multicolumn{2}{|c|}{$\operatorname{Drop~1~}_{\text {Drop } 2}{ }_{\text {Drop }}$} & \multicolumn{2}{|c|}{ Drop $11{ }_{\text {Drop } 2}^{2}$} & \multicolumn{2}{|c|}{$\begin{array}{c}\text { Exp. } 3 \\
\text { Drop 1 }\end{array}$} & \multirow{2}{*}{$\begin{array}{c}\begin{array}{c}\% \\
\text { Response }\end{array} \\
83 \cdot 3 \\
76 \cdot 4 \\
68 \cdot 1 \\
62 \cdot 5 \\
55 \cdot 6 \\
0\end{array}$} & \multirow{2}{*}{$\begin{array}{c}\begin{array}{c}\text { Mean } \\
\text { angular } \\
\text { response }\end{array} \\
67 \cdot 45 \\
62 \cdot 32 \\
55 \cdot 90 \\
52 \cdot 47 \\
48 \cdot 22 \\
8 \cdot 30\end{array}$} \\
\hline & $\begin{array}{c}10^{*} \\
8 \\
6 \\
7 \\
9 \\
0\end{array}$ & $\begin{array}{r}8 \\
12 \\
9 \\
9 \\
7 \\
0\end{array}$ & $\begin{array}{r}12 \\
11 \\
9 \\
9 \\
8 \\
0\end{array}$ & $\begin{array}{r}12 \\
8 \\
10 \\
9 \\
7 \\
0\end{array}$ & $\begin{array}{l}8 \\
8 \\
8 \\
4 \\
6 \\
0\end{array}$ & $\begin{array}{r}10 \\
\mathbf{8} \\
7 \\
7 \\
3 \\
0\end{array}$ & & \\
\hline
\end{tabular}

* The number of morphologically normal blastocysts formed from twelve two-cell embryos after 3 days in culture.

An analysis of variance showed that there was no significant difference between the treatment effect in the three experiments.

of the embryos treated, while the highest concentration caused degeneration of most of the embryos at the two-cell stage. This suggests a fairly steep dose response line for the effect of the compound on early embryos.

Dose response in vivo

The effects of orally administered U-11100A on pregnancy in mice are summarized in Table 2 . The lowest dose which completely blocked pregnancy $\left(\mathrm{ED}_{100}\right)$ in the single dose group was more than twice as large as the total quadruple dose which was necessary to terminate pregnancy. In mice which were treated with doses lower than the $\mathrm{ED}_{100}$, it was observed that there were 


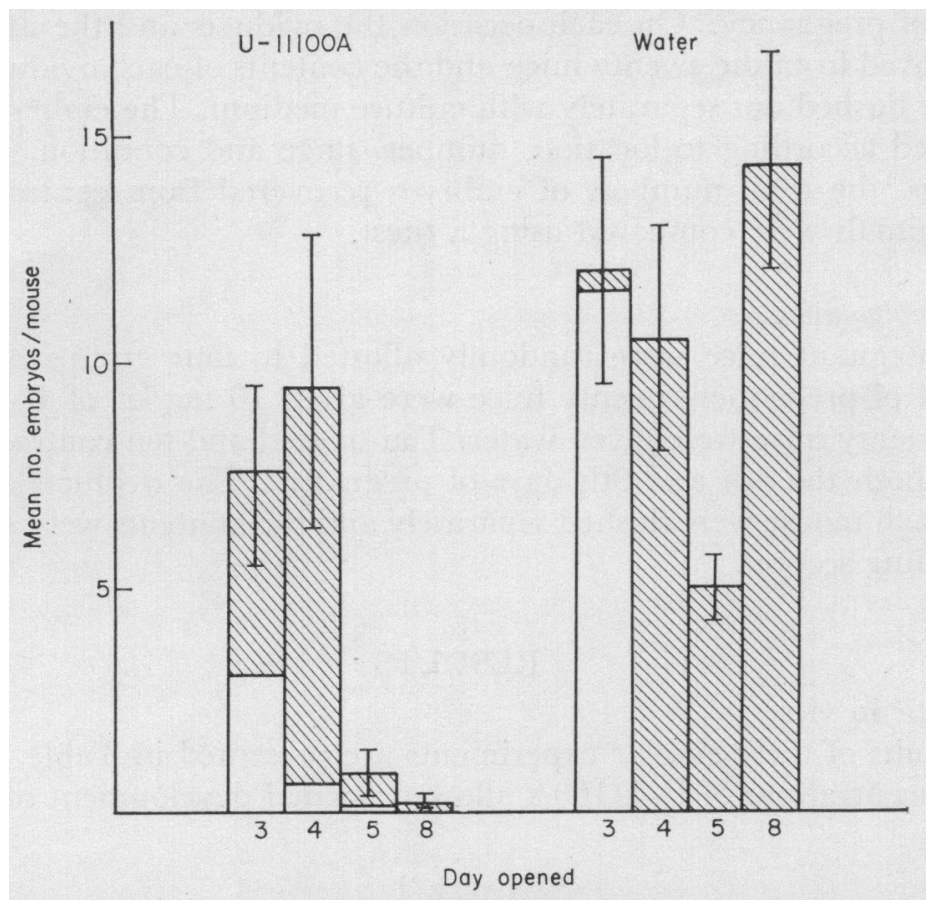

TexT-FIG. 1. Effect of oral administration of $10 \mathrm{mg} / \mathrm{kg}$ of U-11100A on the number and distribution of embryos in the reproductive tracts of treated females. Open columns, oviducts; shaded columns, uterus. Standard errors of the means are represented by the vertical lines.

generally fewer implantation sites per pregnant uterus than in controls. However, the large amount of variation involved makes it difficult to evaluate the significance of the data. It was also noted that treated mice appeared to have conceptuses which were considerably smaller than those of the controls,

TABLE 2

EFFECT OF ORALLY ADMINISTERED U-11100A ON PREGNANCY MAINTENANCE IN MICE

\begin{tabular}{l|c|c|c}
\hline \multicolumn{1}{c|}{$\begin{array}{c}\text { Dose of } \\
U-11100 \mathrm{~A}\end{array}$} & $\begin{array}{c}\text { Exp. 1 } \\
\text { response }\end{array}$ & $\begin{array}{c}\text { Exp. } 2 \\
\text { response }\end{array}$ & $\begin{array}{c}\% \\
\text { response }\end{array}$ \\
\cline { 2 - 3 } Control & $5(21.4)$ & $8(21 \cdot 6)$ & 65.0 \\
$2.5 \mathrm{mg} / \mathrm{kg}$ & $7(9.0)$ & $5(12.6)$ & 60.0 \\
$5 \mathrm{mg} / \mathrm{kg}$ & $3(13.3)$ & $2(3.0)$ & 25.0 \\
$10 \mathrm{mg} / \mathrm{kg}$ & 0 & 0 & 0 \\
\hline $4 \times \mathrm{control}$ & $5(18 \cdot 6)$ & $5(17 \cdot 8)$ & 50.0 \\
$4 \times 0.25 \mathrm{mg} / \mathrm{kg}$ & $2(2.0)$ & $1(6.0)$ & 15.0 \\
$4 \times 0.5 \mathrm{mg} / \mathrm{kg}$ & 0 & $1(12 \cdot 0)$ & 5.0 \\
$4 \times 1.0 \mathrm{mg} / \mathrm{kg}$ & 0 & 0 & 0 \\
\hline
\end{tabular}

Response is number of mice, out of ten per treatment, with implantations. Average numbers of foetuses per pregnant mouse are given in parentheses. 
so that the treated mice actually appeared to be at an earlier stage of pregnancy than the control mice.

\section{Tubal transport rate}

The results of the studies on tubal transport rate are presented in Table 3

TABLE 3

EFFECT OF ORAL ADMINISTRATION OF $10 \mathrm{MG} / \mathrm{KG}$ OF U-11100A ON PREGNANCY IN MICE

\begin{tabular}{|c|c|c|c|c|c|c|c|}
\hline \multirow{2}{*}{$\begin{array}{c}\text { Day of } \\
\text { pregnancy } \\
\text { when opened }\end{array}$} & \multirow{2}{*}{$\begin{array}{l}\text { Normal } \\
\text { stage } \\
\text { present }\end{array}$} & \multirow{2}{*}{$\begin{array}{c}\text { Treatment } \\
\text { on } \\
\text { Day } 2\end{array}$} & \multirow{2}{*}{$\begin{array}{l}\text { Total no. } \\
\text { of embryos } \\
\text { from ten } \\
\text { mice }\end{array}$} & \multicolumn{2}{|c|}{$\begin{array}{l}\text { No. of embryos } \\
\text { from oviducts } \\
\text { of ten mice }\end{array}$} & \multicolumn{2}{|c|}{$\begin{array}{l}\text { No. of embryos } \\
\text { from } \\
\text { uteri of ten mice }\end{array}$} \\
\hline & & & & Total & $\begin{array}{c}\text { Normal } \\
\text { stage }\end{array}$ & Total & $\begin{array}{l}\text { Normal } \\
\text { stage }\end{array}$ \\
\hline 3 & 4-8-cell & $\begin{array}{l}\text { U-11100A } \\
\text { Water }\end{array}$ & $\begin{array}{r}77 \\
119\end{array}$ & $\begin{array}{r}31 \\
116\end{array}$ & $\begin{array}{r}31 \\
114\end{array}$ & $\begin{array}{r}46 \\
3\end{array}$ & $\begin{array}{r}46 \\
3\end{array}$ \\
\hline \multirow[t]{2}{*}{4} & Morula & $\mathrm{U}-11100 \mathrm{~A}$ & 96 & 7 & 7 & 89 & 89 \\
\hline & blastocyst & Water & 105 & 0 & 0 & 105 & 100 \\
\hline 5 & $\begin{array}{c}\text { Late } \\
\text { blastocyst }\end{array}$ & $\begin{array}{l}\text { U-11100A } \\
\text { Water }\end{array}$ & $\begin{array}{l}8^{*} \\
49\end{array}$ & $\begin{array}{l}1 \\
0\end{array}$ & $\begin{array}{l}1 \\
0\end{array}$ & $\begin{array}{r}7 \\
49\end{array}$ & $\begin{array}{r}7 \\
49\end{array}$ \\
\hline 8 & Foetus & $\begin{array}{l}\text { U-11100̣A } \\
\text { Water }\end{array}$ & $\begin{array}{r}41 \\
144\end{array}$ & $\begin{array}{c}39 \dagger \\
0\end{array}$ & $\begin{array}{l}0 \\
0\end{array}$ & $2+$ & $\begin{array}{r}0 \\
144\end{array}$ \\
\hline
\end{tabular}

* Significantly $(P<0.001)$ lower than control.

+ All one-cell.

$\ddagger$ Late blastocysts.

and in Text-fig. 1. In control mice, nearly all of the embryos pass from the oviducts into the uterine horns between the 3rd and 4th days of pregnancy. In mice which received $10 \mathrm{mg} / \mathrm{kg}$ of U-11100A on Day 2 of pregnancy, over half

TABLE 4

EFFECT OF ORAL ADMINISTRATION OF $10 \mathrm{MG} / \mathrm{KG}$ U-11100A ON IMPLANTATION OF BLASTOCYSTS (TEN MICE/TREATMENT)

\begin{tabular}{|c|c|c|c|c|c|c|c|}
\hline \multirow{2}{*}{$\begin{array}{l}\text { Treatment } \\
\text { on Day } 4\end{array}$} & \multirow{2}{*}{$\begin{array}{c}\text { Day } \\
\text { opened }\end{array}$} & \multicolumn{2}{|c|}{ Implanted } & \multicolumn{2}{|c|}{$\begin{array}{l}\text { Late blastocysts } \\
\text { in uterus }\end{array}$} & \multicolumn{2}{|c|}{ Ovulated } \\
\hline & & $\begin{array}{l}\text { No. of } \\
\text { mice }\end{array}$ & $\begin{array}{l}\text { No. of } \\
\text { foetuses }\end{array}$ & $\begin{array}{l}\text { No. of } \\
\text { mice }\end{array}$ & $\begin{array}{l}\text { No. of } \\
\text { embryos }\end{array}$ & $\begin{array}{l}\text { No. of } \\
\text { mice }\end{array}$ & $\begin{array}{l}\text { No. of } \\
\text { ova }\end{array}$ \\
\hline $\begin{array}{l}\text { Water } \\
\text { U-11100A } \\
\text { Water } \\
\text { U-11100A }\end{array}$ & $\begin{array}{l}5 \\
5 \\
9 \\
9\end{array}$ & $\begin{array}{l}0 \\
0 \\
4 \\
0\end{array}$ & $\begin{array}{r}0 \\
0 \\
75 \\
0\end{array}$ & $\begin{array}{l}9 \\
9 \\
2 \\
0\end{array}$ & $\begin{array}{r}68 \\
78 \\
10 \\
0\end{array}$ & $\begin{array}{l}0 \\
0 \\
3 \\
3\end{array}$ & $\begin{array}{r}0 \\
0 \\
26 \\
16\end{array}$ \\
\hline
\end{tabular}

of the embryos had passed into the uterus by Day 3. It was also found that significantly fewer embryos were present in treated mice than in control mice on Days 5 and 8 of pregnancy. (In analysing the data for Day 8, newlyovulated ova in the treated group were not considered.) 


\section{Implantation}

Mice in this experiment were treated on Day 4, when most of the embryos had already reached the uterus. The results of these experiments are given in Table 4. When the mice were examined on Day 5, both the treated and control groups had no embryos in the oviducts and late blastocysts in the uteri of most of the mice. On Day 9, many of the control mice had either implanted foetuses or late blastocysts in the uterus, while none of the treated mice had either embryos or foetuses present in their reproductive tracts.

\section{DISCUSSION}

The dose of U-11100A which was found to be necessary to interfere with pregnancy in mice $(10 \mathrm{mg} / \mathrm{kg})$ is somewhat higher than the effective dose in rats and rabbits. Single doses of $0.4 \mathrm{mg} / \mathrm{kg}$ (Greenwald, 1965), $0.3 \mathrm{mg} / \mathrm{kg}$ (Nelson, Davidson \& Wada, 1963) and $0.25 \mathrm{mg} / \mathrm{kg}$ (Duncan, Lyster, Clark \& Lednicer, 1963) were found to terminate pregnancy in the rat. Duncan et al. (1963) found that daily doses of more than $0.025 \mathrm{mg} / \mathrm{kg} \mathrm{U}-11100 \mathrm{~A}$, during the period from pro-oestrus to Day 6, were sufficient to block pregnancy. It was found that $5 \mathrm{mg} / \mathrm{kg}$ on Day 1 of pregnancy was effective in rabbits (Morris, van Wagenen, McCann \& Jacob, 1967), as well as 0.5 to $2.0 \mathrm{mg} / \mathrm{kg}$ on Days 1,2 and 3 (Morris et al., 1967; Chang \& Yanagimachi, 1965). The higher doses required for effectiveness in mice may be due to a species difference or might reflect small differences in technical detail, such as administration vehicle and method of gavaging. The difference in total effective doses, as far as the single- and multiple-dose regimens are concerned, suggests that the compound acts over a period of several days, rather than having a single direct effect.

A comparison of effective doses in vitro and in vivo is difficult, unless one knows the amount of U-11100A which actually reaches the Fallopian tubes. If, for purposes of discussion, one assumes an even distribution of the ingested compound throughout the body, a concentration of $10 \mu \mathrm{g} / \mathrm{g}$ would be present in all areas. This is in the same range as the effective concentration in vitro of $20 \mu \mathrm{g} / \mathrm{ml}$, and does not therefore exclude the possibility of a direct action on the zygote.

It was noticed in scoring the pregnancy experiments that the foetuses of mice treated with sub-effective doses of U-11100A were both fewer in number and smaller in size than those of the controls. The smaller litter sizes suggest that not all of the fertilized embryos implant in treated mothers, while the smaller size of the foetuses suggests that those embryos which implant in treated mothers do so several days later than those in control mothers. The same effect was found in rats by Nelson et al. (1963).

In studying in more detail the mode of action of the compound, it was found that pregnancy can be blocked either while the zygotes are still in the oviduct or after the blastocysts have reached the uterus. When the compound was given on Day 2, many of the embryos had passed from the oviduct to the uterus by Day 3, while this was not true of control mice. In addition, significantly fewer embryos were recovered from treated mice than from control mice on Day 5, which suggests that many of the blastocysts from treated mice pass rapidly out through the vagina. Acceleration of tubal transport and vaginal 
loss, as a result of administration of U-11100A, have also been found in rabbits (Chang \& Yanagimachi, 1965) and in rats (Greenwald, 1965; Duncan \& Forbes, 1965). This is in contrast to the tubal retention caused in mice by clomiphene and U-11555A (Thomson, 1968b).

In all cases most of the recovered embryos were at the proper stage of development and appeared to be morphologically normal. This indicates that at pregnancy-blocking levels there is no direct deleterious effect on the zygotes.

When the compound was fed on Day 4, the day on which nearly all embryos have reached the uterus, U-11100A was effective at the same dose used on Day 2. Although normal complements of late blastocysts were recovered from the uteri of treated mice on the following day, there were no blastocysts present on Day 9, and no implantation had occurred. Thus it is possible that the compound may interfere directly with implantation. Greenwald (1965) found that the induction of decidual reactions in rats was inhibited by U-11100A, while Morris et al. (1967) found that sub-effective doses of the compound caused degenerative changes in the implantation sites in pregnant rabbits.

Thus it appears that, in mice, U-11100A acts to end pregnancy by affecting the maternal reproductive system, rather than by direct effects on the embryo. This is accomplished either because the embryo is passed too rapidly through the tract and/or because the uterus is unable to undergo the changes which normally precede implantation.

\section{ACKNOWLEDGMENTS}

This investigation was supported by a grant from the National Institutes of Health (HD-02315-02). The U-11100A was donated by Dr Gordon W. Duncan of the Upjohn Company.

The authors gratefully acknowledge the excellent technical assistance of Miss Mary Ryans, Mrs Margaret van Meter and Miss Shelly Walker.

\section{REFERENCES}

Biggers, J. D. \& Brinster, R. L. (1965) Biometrical problems in the study of early mammalian embryos in vitro. F. exp. Zool. 158, 39.

Brinster, R. L. (1963) A method for in vitro cultivation of mouse ova from two-cell to blastocyst. Expl Cell Res. 32, 205.

BRINSTER, R. L. (1965) Studies on the development of mouse embryos in vitro. IV. Interaction of energy sources. F. Reprod. Fert. 10, 227.

Chang, M. C. \& Yanagimachi, R. (1965) Effect of estrogens and other compounds as oral antifertility agents on the development of rabbit ova and hamster embryos. Fert. Steril. 16, 281.

Duncan, G. W. \& ForBes, A. D. (1965) Blastocyst survival and nidation in rats treated with oestrogen antagonists. F. Reprod. Fert. 10, 161.

Duncan, G. W., Lyster, S. C., Clark, J. J. \& Lednicer, D. (1963) Antifertility activities of two diphenyldihydronaphthalene derivatives. Proc. Soc. exp. Biol. Med. 112, 439.

GreEnwaLd, G. S. (1965) Effects of a dihydronaphthalene derivative (U-11100A) on pregnancy in the rat. Fert. Steril. 16, 185.

Morris, J. M., van WAgEnen, G., McCanN, T. \& JAGOB, D. (1967) Compounds interfering with ovum implantation and development. II. Synthetic estrogens and anti-estrogens. Fert. Steril. 18, 18.

Nelson, W. O., Davidson, O. W. \& WADA, K. (1963) Studies on interference with zygote development and implantation. In: Delayed Implantation. Ed. A. C. Enders. University of Chicago Press.

Thomson, J. L. (1968a) Effect of two nonsteroidal antifertility agents on pregnancy in mice. I. Comparison of in vitro and in vivo effects on zygotes. F. Reprod. Fert. 15, 223.

Thomson, J. L. (1968b) Effect of two nonsteroidal antifertility agents on pregnancy in mice. II. Effects on tubal transport rate and implantation. F. Reprod. Fert. 16, 363. 